\title{
Urotensin-II and UII-receptor expression and function in the rat adrenal cortex
}

\author{
GIOVANNA ALBERTIN ${ }^{1}$, VALENTINA CASALE ${ }^{1}$, AGNIESZKA ZIOLKOWSKA ${ }^{3}$, RAFFAELLA SPINAZZI ${ }^{1}$, \\ LUDWIK K. MALENDOWICZ ${ }^{3}$, GIAN PAOLO ROSSI ${ }^{2}$ and GASTONE G. NUSSDORFER ${ }^{1}$

\begin{abstract}
Departments of ${ }^{1}$ Human Anatomy and Physiology, Section of Anatomy, and ${ }^{2}$ Clinical and Experimental Medicine, School of Medicine, University of Padua, I-35121 Padua, Italy; ${ }^{3}$ Department of Histology and Embryology, Karol Marcinkowska University of Medical Sciences, PL-60781 Poznan, Poland
\end{abstract}

Received January 24, 2006; Accepted March 16, 2006

\begin{abstract}
Urotensin-II (UII) is a potent hypertensive peptide, which has been recognized as an endogenous ligand of the G protein-coupled receptor (GPR)-14, now named UT-R. Real-time PCR demonstrated the expression of UII and UT-R mRNAs in both dispersed and in vitro cultured rat adrenocortical cells. UII concentration-dependently decreased basal, but not ACTH-stimulated, corticosterone secretion from cultured adrenocortical cells, and the effect was abolished by the UT-R antagonist Palosuran. UII did not affect the proliferation rate of cultured cells. Taken together, these findings suggest that UII may be included in the group of peptides (adrenomedullin, atrial natriuretic peptide, neurotensin and beacon), that, acting in an autocrine-paracrine manner, are involved in the inhibitory tuning of adrenocortical secretion.
\end{abstract}

\section{Introduction}

Urotensin-II (UII) is an 11- (human) or 14-amino acid peptide (rat), originally isolated from the fish urophysis (1), that exerts a potent vasoconstrictory activity (2-4). UII has been identified as an endogenous ligand of the $\mathrm{G}$ protein-coupled receptor (GPR)-14, now named UT-R (2,5-7). The wide distribution of UII and UT-R in the heart and large arteries, coupled to the strong hypertensive effect of UII, led to the conclusion that this peptide may play an important role in the physiology and pathophysiology of the cardiovascular (CV) system (8-12).

Evidence has been also provided that UII and UT-R are expressed in the adrenal gland and adrenal tumors (13-17), and UII has been reported to enhance proliferative activity of

Correspondence to: Professor G.G. Nussdorfer, Department of Human Anatomy and Physiology, Section of Anatomy, Via Gabelli 65, I-35121 Padova, Italy

E-mail: gastone.nusdorfer@unipd.it

Key words: urotensin-II, urotensin receptor, urotensin-receptor antagonists, Palosuran, adrenal cortex, glucocorticoid secretion, rat human adrenocortical carcinoma-derived SW-13 cells cultured in vitro $(14,18)$. Due to its hypertensive effect and CV and adrenal distribution, UII has been compared to endothelin (ET)-1 $(14,19,20)$.

ET-1 is know to exert not only a strong proliferogenic but also a major secretagogue action on the adrenal cortex (reviewed in ref. 21), and this prompted us to study the expression of UII and UT-R genes in rat adrenocortical cells and to examine whether UII affects their in vitro secretion and growth.

\section{Materials and methods}

Animals and reagents. Adult male Sprague-Dawley rats ( 200 g body weight) were purchased from Charles-River (Como, Italy), and the experiment protocol was approved by the local Ethics Committee for Animal Studies. Rat UII was obtained from Neosystem Laboratoires (Strasbourg, France), and the UT-R antagonist (UT-RA) Palosuran (ACT-058362) (22) was a generous gift of Dr M. Clozel (Actelion Pharmaceuticals Ltd., Allschwil, Switzerland). Collagenase and deoxyribonuclease were provided by Worthington Biochemical Corp. (Lake Wood, NJ), and iTaq DNA polymerase from Bio-Rad Laboratories (Milan, Italy). ACTH, Dulbecco's modified Eagle's medium (DMEM), fetal calf serum (FCS), bovine serum albumin (BSA), and all other chemicals and reagents were purchased from Sigma-Aldrich Corp. (St. Louis, MO).

Dispersed cell. Rats were decapitated, and their adrenals promply removed under sterile conditions. Adrenals were decapsulated to separate zona glomerulosa, and then halved and enucleated to eliminate medullary chromaffin tissue. Dispersed zona fasciculata-reticularis (inner) cells were obtained by sequential enzymatic digestion (collagenase-I, $2 \mathrm{mg} / \mathrm{ml}$ and deoxyribonuclease- $\mathrm{I}, 0.1 \mathrm{mg} / \mathrm{ml}$ in DMEM) and mechanical disaggregation.

In vitro culture. Dispersed inner adrenocortical cells were seeded at a density of $2 \times 10^{4}$ cells $/ \mathrm{cm}^{2}$ in 24 -well polystyrene plates, and cultured for $72 \mathrm{~h}$ at $37^{\circ} \mathrm{C}$ in DMEM (added with $1.125 \mathrm{~g} / 1$ sodium bicarbonate, $10 \%$ FCS, $100 \mathrm{U} / \mathrm{ml}$ penicillin and $100 \mu \mathrm{g} / \mathrm{ml}$ streptomycin) in an atmosphere of 


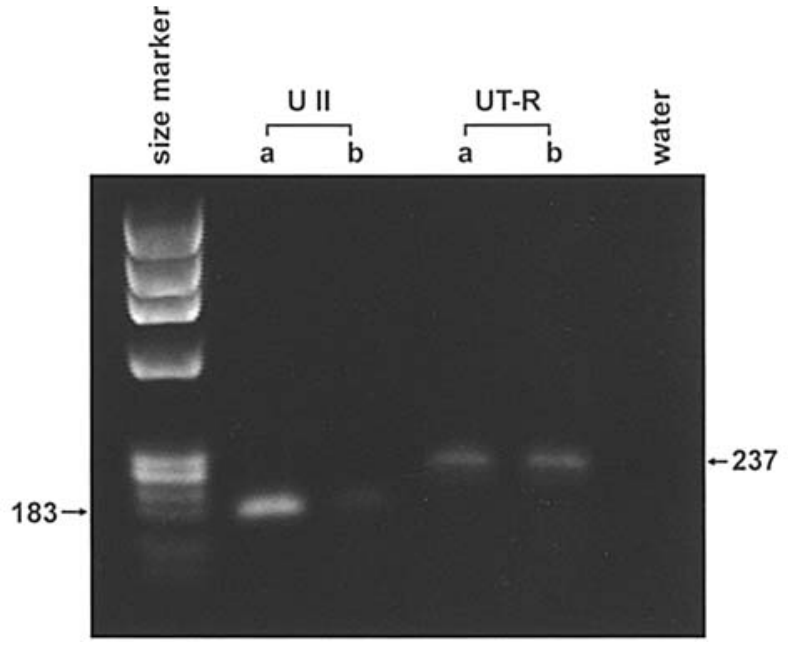

Figure 1. Ethidium bromide-stained $2 \%$ agarose gel electrophoresis showing cDNA amplified with rat UII and UT-R specific primers from RNA of exemplary freshly-dispersed (a) and cultured rat adrenocortical-cell samples (b). The first lane was loaded with Roche Marker VIII. No amplification with water instead of RNA is shown as negative control.

$95 \%$ air-5\% $\mathrm{CO}_{2}$, medium being changed every $24 \mathrm{~h}(23,24)$. At day 3 of culture, cells were incubated for $24 \mathrm{~h}$ as follows: i) UII (from $10^{-10}$ to $10^{-6} \mathrm{M}$ ); ii) ACTH $\left(10^{-8} \mathrm{M}\right.$ ) alone or in the presence of $10^{-6} \mathrm{M} \mathrm{UII}$; and iii) UT-RA (from $10^{-7}$ to $10^{-5} \mathrm{M}$ ) alone or in the presence of $10^{-6} \mathrm{M}$ UII and $10^{-8} \mathrm{M}$ ACTH. Control (baseline) cultures were incubated without any chemical. Medium was collected and stored at $-80^{\circ} \mathrm{C}$.

Reverse transcription $(R T)$-real-time polymerase chain reaction $(P C R)$. Freshly dispersed and cultured control inner adrenocortical cells were harvested and frozen. Total RNA was extracted and reverse transcribed to cDNA (25-28). The RTreaction solution $(1 \mu \mathrm{l})$ was added to a mixture (final volume, $25 \mu \mathrm{l}$ ), containing $50 \mathrm{mM} \mathrm{KCl}, 20 \mathrm{mM}$ Tris- $\mathrm{HCl}$ (pH 8.4), $3 \mathrm{mM} \mathrm{MgCl} 2,0.8 \mathrm{mM}$ dNTPs and $25 \mathrm{U} / \mu 1$ iTaq DNA polymerase (29-31). Real-time PCR was performed in a Bio-Rad I-Cycler iQ detection system, using the following protocol: denaturation $\left(95^{\circ} \mathrm{C}\right.$ for $\left.3 \mathrm{~min}\right), 35$ cycles of two steps of amplification $\left(95^{\circ} \mathrm{C}\right.$ for $15 \mathrm{sec}$ and annealing for $\left.30 \mathrm{sec}\right)$, and melting curve $\left(60-90^{\circ} \mathrm{C}\right.$ with a heating rate of $\left.0.5^{\circ} \mathrm{C} / 10 \mathrm{sec}\right)$. Primer sequences, annealing temperature and the predicted size of amplicons were: i) UII (NM_019160): sense-131-5', 5'-AG CTTCCAGTGCTTGAGGAA-3' and antisense-314-3', 5'-GA ATCTTGCCCAGTGAGAGC-3' $\left(60^{\circ} \mathrm{C} ; 183 \mathrm{bp}\right)$; and ii) UT-R (NM_020537): sense-80-5', 5'-ACTCCAACgTgTCCCTCA AC-3' and antisense-317-3', 5'-AAGGGAATGCTCAGCAG GTA-3' $\left(60^{\circ} \mathrm{C} ; 237 \mathrm{bp}\right)$. The specifity of amplification was tested at the end of each run by real-time PCR melting analysis, using the I-Cycler iQ software 3.0.

Corticosterone assay. Corticosterone concentration in the incubation media was measured by radioimmune assay, as previously detailed (32). Intra- and inter-assay CVs were $7.0 \%$ and $8.3 \%$, respectively.

Cell proliferation. The proliferation rate of cultured cells was assayed by the EZ4U non-radioactive cell proliferation and

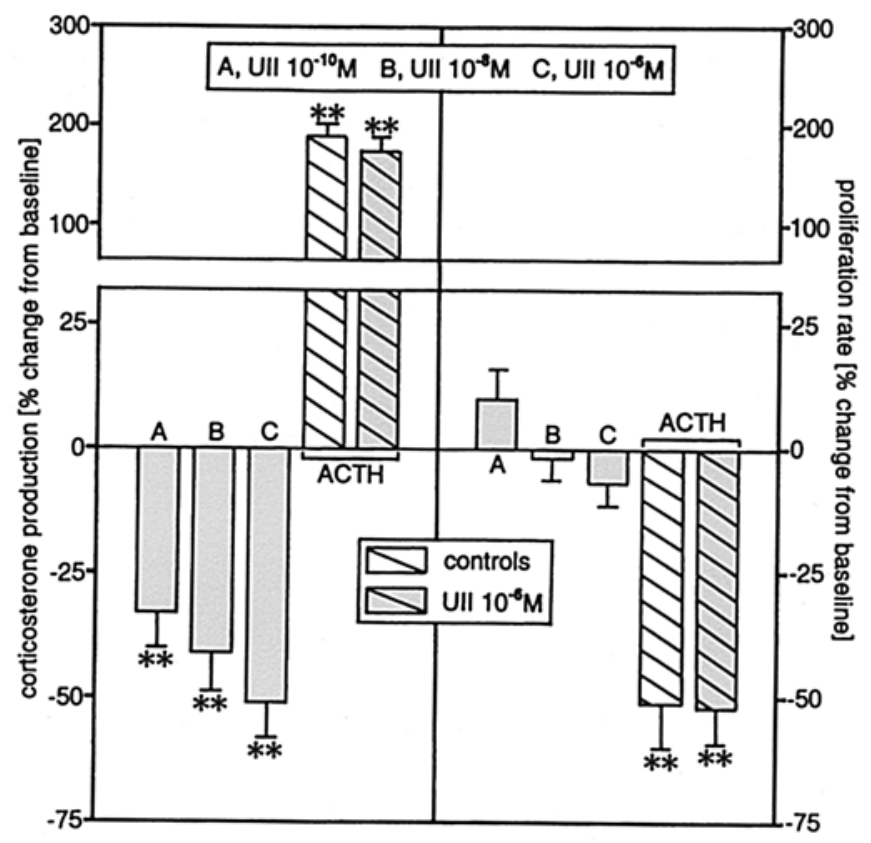

Figure 2. Effects of UII on basal and ACTH-stimulated corticosterone production from (left panel) and basal and ACTH-inhibited proliferative activity of (right panel) rat inner adrenocortical cells cultured in vitro. Results are expressed as percent change from baseline and are the mean \pm SEM of 6 separate experiments. ${ }^{* *} \mathrm{p}<0.01$ from the respective baseline value.

cytotoxic assay of Biomedica (Vienna, Austria), as described earlier $(33,34)$. Briefly, cultured cells were incubated for the last $5 \mathrm{~h}$ with EZ4U, and formazan production, which is linearly related to the cell number, was assayed by measuring absorbance at $490 \mathrm{~nm}$ wavelength in a microplate autoreader EL-13 (Bio-Tek Instruments, Winooski, VT).

Statistics. Results were expressed as percent change from baseline, and were the mean \pm SEM of six separate experiments. The statistical comparison was performed by ANOVA, followed by the multiple range test of Duncan.

\section{Results}

RT-PCR revealed UII and UT-R mRNA expression in both freshly dispersed and cultured rat adrenocortical cells (Fig. 1). Real-time PCR melting curve analysis showed well-defined peaks for UII and UT-R genes; thus, ruling out amplification of non-specific products.

UII concentration-dependently lowered basal corticosterone secretion from cultured rat inner adrenocortical cells, without significantly altering the ACTH-stimulated one (Fig. 2). The inhibitory effect of UII was counteracted by UT-RA in a concentration-dependent manner. UT-RA per se neither affected basal corticosterone production nor changed the ACTH-stimulated one (Fig. 3). UII did not induce significant changes in either basal or ACTH-suppressed proliferation rate of cultured adrenocortical cells (Fig. 2).

\section{Discussion}

Our RT-PCR findings, showing the expression of UII and UT-R in both freshly dispersed and cultured rat adrenocortical 


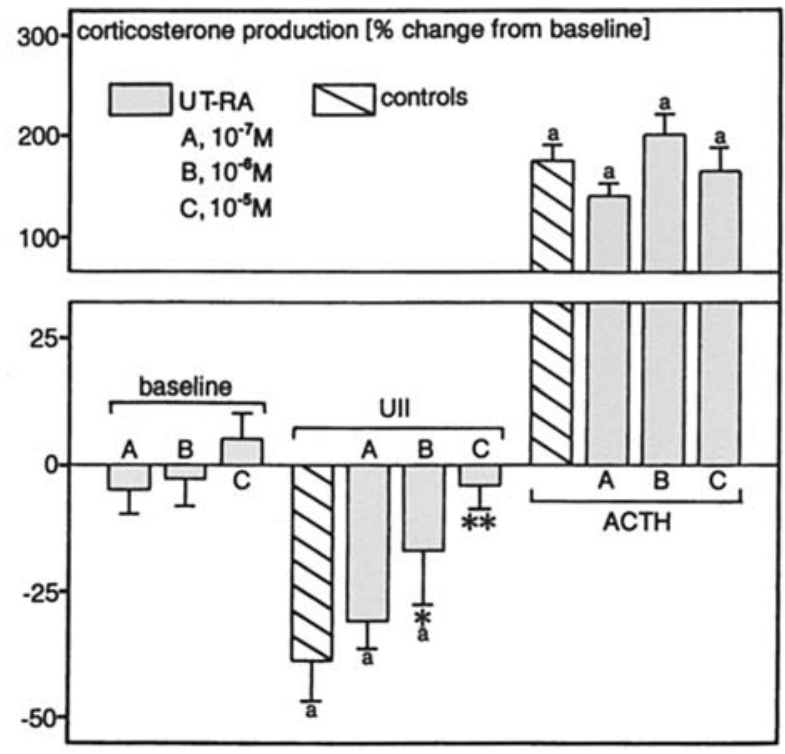

Figure 3. Effect of UT-RA on basal, UII-inhibited and ACTH-stimulated corticosterone production from rat inner adrenocortical cells cultured in vitro. Results are expressed as percent change from baseline and are the mean \pm SEM of 6 separate experiments. ${ }^{a} \mathrm{p}<0.01$ from the respective baseline value; ${ }^{*} \mathrm{p}<0.05$ and ${ }^{* *} \mathrm{p}<0.01$ from the respective control value.

cells, confirm earlier results $(13,16)$ and rule out the possibility that the expression can be ascribed to the extraparenchymal components of the gland (capillary and stromal fibroblasts). Hence, they may suggest a possible autocrine-paracrine mechanism of action of UII in the adrenal cortex, as seems to occur in other peripheral tissues (reviewed in ref. 17). However, our data do not conclusively prove that UII and UT-R genes are expressed at the protein level in adrenals, and further Western blot and immunocytochemical studies are underway to address this issue.

Despite the fact that UII has been claimed to be the new ET-1 (19), we were unable to find a stimulating action of this peptide on the secretory activity of adrenocortical cells. Conversely, our study provides evidence for an inhibitory action of UII on basal, but not ACTH-stimulated, glucocorticoid secretion. The effect appears to be mediated by the UT-R because it is abrogated by the selective UT-RA Palosuran (22). Of interest, the putative UT-RA SB-710411 (35) was ineffective in counteracting the UII antisecretagogue action, suggesting that Palosuran is to be considered the elective drug in the investigations on the adrenal effect of UII.

The comparison of UII to ET-1 was based on the following main lines of evidence: i) UII is the most potent mammalian vasoconstrictor (3), and its plasma concentration was found to be markedly elevated in hypertensive subjects $(10,36)$ and in patients with congestive heart failure (37-40); ii) high UII expression has been detected in coronary atherosclerotic lesions $(16,41)$. Taken together, these observations, coupled to the demonstration that UII induces cardiomyocyte hypertrophy $(42,43)$ and cardiac fibrosis $(8,44)$, led to the conclusion that this peptide, such as ET-1 $(45,46)$, may play a deleterious role in the progression of $\mathrm{CV}$ diseases (9-12). However, in the normal heart UII has been shown to exert a strong inotropic effect (47), and a sustained COX- and NO-dependent coronary vasodilatory action (48). Moreover, UII has been recently reported to induce hypotensive responses in both normotensive and spontaneously hypertensive rats (49). These findings are reminiscent of those obtained with the vasodilatory peptide adrenomedullin (AM), which, along with its receptors, is expressed in vessels and heart $(50,51)$ and is thought to exert a major $\mathrm{CV}$ protective action (reviewed in ref. 52). This, along with our present findings indicating that UII, such as AM (53), suppresses the secretory activity of the adrenal cortex, could suggest that UII, at least under normal conditions, is to be considered the novel AM, more than the new ET-1.

In keeping with previous findings $(32-34,54)$, ACTH was found to inhibit in vitro growth of rat adrenocortical cells, thereby confirming that the stimulation of specialized secretory functions of adrenocortical cells cultured in vitro is coupled with the inhibition of their proliferative activity (reviewed in ref. 55). Although both ET-1 and AM have been shown to exert a clearcut growth-promoting action on adrenocortical cells (reviewed in refs. 21,53), our investigation does not reveal any sizeable effect of UII on the proliferation rate of cultured rat inner cells. This observation disagrees with the reported proliferogenic effect of UII on SW-13 cells $(14,18)$, but it must be taken into account that the physiology of this human adrenocortical carcinoma-derived cell line does not surely reflect that of normal adrenocortical cells (26).

Compelling evidence indicates that several peptides synthesized in adrenal glands are able to control adrenocortical secretion acting in an autocrine-paracrine manner (reviewed in refs. 56,57). Although a large part of these peptides exert a secretagogue effect, others, in addition to AM (53), possess a marked inhibitory action: atrial natriuretic peptide (58-61), neurotensin $(62,63)$, leptin (64$66)$ and beacon $(27,31,33,67)$. Our study provides the first evidence that UII may be included in this last group of peptides involved in the fine-tuning of adrenocortical secretion.

\section{References}

1. Pearson D, Shively JE, Clark BR, Geschwind II, Barkley M, Nishioka RS and Bern HA: Urotensin II: a somatostatin-like peptide in the caudal neurosecretory system of fishes. Proc Natl Acad Sci USA 77: 5021-5024, 1980.

2. Ames RS, Sarau HM, Chambers JK, Willette RN, Aiyar NV, Romanic AM, Louden CS, Foley JJ, Sauermelch CF, Ao Z, Coatney RW, Disa J, Holmes SD, Stadel JM, Martin JD, Liu WS, Glover GI, Wilson S, McNulty DE, Ellis CE, Elshourbagy NA, Shabon U, Trill JJ, Hay DWP, Ohlstein EH, Bergsma DJ and Douglas SA: Human urotensin-II is a potent vasoconstrictor and agonist for the orphan receptor GPR14. Nature 401: 282-286, 1999.

3. Douglas SA and Ohlstein EH: Human urotensin-II, the most potent mammalian vasoconstrictor identified to date, as a therapeutic target for the management of cardiovascular disease. Trends Cardiovasc Med 10: 229-237, 2000.

4. Douglas SA, Sulpizio AC, Piercy V, Sarau HM, Ames RS, Aiyar NV, Ohlstein EH and Willette RN: Differential vasoconstrictor activity of human urotensin-II in vascular tissue isolated from the rat, mouse, dog, pig, marmoset and cynomolgus monkey. Br J Pharmacol 131: 1262-1274, 2000.

5. Liu Q, Pong SS, Zeng Z, Zhang Q, Howard AD, Williams DL Jr, Davidoff M, Wang R, Austin CP, McDonald TP, Bai C, George SR, Evans JF and Caskey CT: Identification of urotensin II as the endogenous ligand for the orphan G-protein-coupled receptor GPR14. Biochem Biophys Res Commun 266: 174-178, 1999. 
6. Mori M, Sugo T, Abe M, Shimomura Y, Kurihara M, Kitada C, Kikuchi K, Shintani Y, Kurokawa T, Onda H, Nishimura O and Fujino M: Urotensin II is the endogenous ligand of a G-proteincoupled orphan receptor, SENR (GPR14). Biochem Biophys Res Commun 265: 123-129, 1999 .

7. Carotenuto A, Grieco P, Novellino E and Rovero P: UrotensinII receptor peptide agonists. Med Res Rev 24: 577-588, 2004.

8. Kompa AR, Thomas WG, See F, Tzanidis A, Hannan RD and Krum H: Cardiovascular role of urotensin II: effect of chronic infusion in the rat. Peptides 25: 1783-1788, 2004.

9. Richards AM and Charles C: Urotensin II in the cardiovascular system. Peptides 25: 1795-1802, 2004.

10. Russell FD and Molenaar P: Cardiovascular actions of human urotensin II: considerations for hypertension. Naunyn Schmiedebergs Arch Pharmacol 369: 271-273, 2004.

11. Thanassoulis G, Huyhn T and Giaid A: Urotensin II and cardiovascular diseases. Peptides 25: 1789-1794, 2004

12. Watson AMD and May CN: Urotensin II, a novel peptide in central and peripheral cardiovascular control. Peptides 25: $1759-1766,2004$

13. Totsune K, Takahashi K, Arihara Z, Sone M, Satoh F, Ito S, Kimura Y, Sasano H and Murakami O: Role of urotensin II in patients on dialysis. Lancet 358: 810-811, 2001

14. Takahashi K, Totsune K, Murakami O, Arihara Z, Noshiro T, Hayashi Y and Shibahara S: Expression of urotensin II and its receptor in adrenal tumors and stimulation of proliferation of cultured tumor cells by urotensin II. Peptides 24: 301-306, 2003.

15. Tamura $\mathrm{K}$, Okazaki $\mathbf{M}$, Tamura $\mathrm{M}$, Isozumi $\mathrm{K}$, Tasaki $\mathrm{H}$ and Nakashima Y: Urotensin II-induced activation of extracellular signal-regulated kinase in cultured vascular smooth muscle cells: involvement of cell adhesion-mediated integrin signaling. Life Sci 72: 1049-1060, 2003

16. Maguire JJ, Kuc RE, Wiley KE, Kleinz MJ and Davenport AP Cellular distribution of immunoreactive urotensin-II in human tissues with evidence of increased expression in atherosclerosis and a greater constrictor response of small compared to large coronary arteries. Peptides 25: 1767-1774, 2004.

17. Yoshimoto T, Matsushita M and Hirata Y: Role of urotensin II in peripheral tissue as an autocrine/paracrine growth factor. Peptides 25: 1775-1781, 2004.

18. Takahashi K, Totsune K, Murakami O and Shibahara S: Expression of urotensin II and urotensin II receptor mRNAs in various human tumor cell lines and secretion of urotensin II-like immunoreactivity by SW-13 adrenocortical carcinoma cells. Peptides 22: 1175-1179, 2001

19. Maguire JJ and Davenport AP: Is the urotensin-II the new endothelin? Br J Pharmacol 137: 579-588, 2002.

20. Onan D, Hannan RD and Thomas WG: Urotensin-II: the old kid in town. Trends Endocrinol Metab 15: 175-182, 2004

21. Nussdorfer GG, Rossi GP, Malendowicz LK and Mazzocchi G: Autocrine-paracrine endothelin system in the physiology and pathology of steroid secreting tissues. Pharmacol Rev 51: 403-438, 1999.

22. Clozel M, Binkert C, Birker-Robaczewska M, Boukhadra C, Ding SS, Fischli W, Hess P, Mathys B, Morrison K, Müller C, Müller C, Nayler O, Qiu C, Rey M, Scherz MW, Velker J, Weller T, Xi JF and Ziltener P: Pharmacology of the urotensinII receptor antagonist palosuran (ACT-058362; 1-[2-(4-benzyl4-hydroxy-piperidin-1-yl)-ethyl]-3-(2-methyl-quinolin-4-yl)urea sulfate salt): first demonstration of a pathophysiological role of the urotensin system. J Pharmacol Exp Ther 311: 204-212, 2004.

23. Malendowicz LK, Spinazzi R, Tortorella C, Nussdorfer GG, Ziolkowska A and Rucinski M: Effects of leptin and leptin fragments on corticosterone secretion and growth of cultured rat adrenocortical cells. Int J Mol Med 14: 873-877, 2004.

24. Rucinski M, Albertin G, Spinazzi R, Ziolkowska A, Nussdorfer GG and Malendowicz LK: Cerebellin in the rat adrenal gland: gene expression and effects of CER and [desSer ${ }^{1}$ CER on the secretion and growth of cultured adrenocortical cells. Int J Mol Med 15: 411-415, 2005.

25. Mazzocchi G, Rossi GP, Neri G, Malendowicz LK, Albertin G and Nussdorfer GG: 11ß-Hydroxysteroid dehydrogenase expression and activity in the human adrenal cortex. FASEB J 12: $1533-1539,1998$

26. Albertin G, Carraro G, Petrelli L, Guidolin D, Neri G and Nussdorfer GG: Endothelin-1 and adrenomedullin enhance the growth of human adrenocortical carcinoma-derived SW-13 cell line by stimulating proliferation and inhibiting apoptosis. Int J Mol Med 15: 469-474, 2005.
27. Ziolkowska A, Rucinski M, Di Liddo R, Nussdorfer GG and Malendowicz LK: Expression of the beacon gene in the rat adrenal glands: direct inhibitory effect of beacon [47-73] on aldosterone secretion from dispersed adrenal zona glomerulosa cells. Int J Mol Med 13: 215-219, 2004.

28. Albertin G, Rucinski M, Carraro G, Forneris M, Andreis P, Malendowicz LK and Nussdorfer GG: Adrenomedullin and vascular endothelium growth factor genes are overexpressed in the regenerating rat adrenal cortex, and AM and VEGF reciprocally enhance their mRNA expression in cultured rat adrenocortical cells. Int J Mol Med 16: 431-435, 2005.

29. Albertin G, Carraro G and Nussdorfer GG: Human adrenomedullin gene silencing by short interfering RNAs: a preliminary study. Int J Mol Med 15: 579-583, 2005.

30. Andreis PG, Rucinski M, Neri G, Conconi MT, Petrelli L, Parnigotto PP, Malendowicz LK and Nussdorfer GG: Neuropeptides B and W enhance the growth of human adrenocortical carcinoma-derived NCI-H295 cells by exerting MAPK p42/p44mediated proliferogenic and antiapoptotic effects. Int J Mol Med 16: 1021-1028, 2005.

31. Rucinski M, Andreis PG, Ziolkowska A, Nussdorfer GG and Malendowicz LK: Differential expression and function of beacon in the rat adrenal cortex and medulla. Int J Mol Med 16: $35-40,2005$.

32. Hochol A, Albertin G, Nussdorfer GG, Spinazzi R, Ziolkowska A, Rucinski M and Malendowicz LK: Effects of neuropeptides B and $\mathrm{W}$ on the secretion and growth of rat adrenocortical cells. Int J Mol Med 14: 843-847, 2004.

33. Ziolkowska A, Carraro G, Rebuffat P, Spinazzi R, Nussdorfer GG, Rucinski M and Malendowicz LK: Beacon[47-73] inhibits glucocorticoid secretion and growth of cultured rat and human adrenocortical cells. Int J Mol Med 14: 457-461, 2004.

34. Spinazzi R, Ziolkowska A, Neri G, Nowak M, Rebuffat P, Nussdorfer GG, Andreis PG and Malendowicz LK: Orexins modulate the growth of cultured rat adrenocortical cells, acting through type 1 and type 2 receptors coupled to the MAPK p42/ p44- and p38-dependent cascades. Int J Mol Med 15: 847-852, 2005.

35. Behm DJ, Herold CL, Ohlstein EH, Knight SD, Dhanak D and Douglas SA: Pharmacological characterization of SB-710411 (Cpa-c[D-Cys-Pal-D-Trp-Lys-Val-Cys]-Cpa-amide), a novel peptidic urotensin-II receptor antagonist. Br J Pharmacol 137 : 449-458, 2002

36. Cheung BMY, Leung R, Man YB and Wong LYF: Plasma concentration of urotensin II is raised in hypertension. J Hypertens 22: 1341-1344, 2004

37. Douglas SA, Tayara L, Ohlstein EH, Halawa N and Giaid A: Congestive heart failure and expression of myocardial urotensin II. Lancet 359: 1990-1997, 2002.

38. Ng LL, Loke I, O'Brien RJ, Squire IB and Davies JE: Plasma urotensin in human systolic heart failure. Circulation 106: 2877-2880, 2002

39. Richards AM, Nichols MG, Lainchbury JG, Fisher S and Yandle TG: Plasma urotensin II in heart failure. Lancet 360: 545-546, 2002.

40. Russell FD, Meyers D, Galbraith AJ, Bett N, Toth I, Kearns P and Molenaar P: Elevated plasma levels of human urotensin-II immunoreactivity in congestive heart failure. Am J Physiol 285: H1576-H1581, 2003

41. Hassan GS, Douglas SA, Ohlstein EH and Giaid A: Expression of urotensin-II in human coronary atherosclerosis. Peptides 26: 2464-2472, 2005

42. Zhou Y, Nagai R and Yamazaki T: Urotensin II induces hypertropic responses in cultured cardiomyocytes from neonatal rats. FEBS Lett 508: 57-60, 2001

43. Johns DG, Ao Z, Naselsky D, Herold CL, Sarov-Blat L, Maniscalco K, Steplewski K, Aiyar N and Douglas SA: Urotensin-II-mediated cardiomyocyte hypertrophy: the effect of receptor antagonism and role of inflammatory mediators. Naunyn Schmiedebergs Arch Pharmacol 370: 238-250, 2004.

44. Tzanidis A, Hannan RD, Thomas WG, Onan D, Autelitano DJ, See F, Kelly DJ, Gilbert RE and Krum H: Direct actions of urotensin II on the heart: implications for cardiac fibrosis and hypertrophy. Circ Res 93: 246-253, 2003.

45. Kedzierski RM and Yanagisawa M: Endothelin system: the double-edged sword in health and disease. Annu Rev Pharmacol 41: 851-876, 2001.

46. Rossi GP, Seccia MT and Nussdorfer GG: Reciprocal regulation od endothelin-1 and nitric oxide: relevance in the physiology 
and pathology of the cardiovascular system Int Rev Cytol 209: 241-272, 2001.

47. Russell FD, Molenaar P and O'Brien DM: Cardiostimulant effects of urotensin-II in human heart in vitro. Br J Pharmacol 132: 5-9, 2001.

48. Katano Y, Ishihata A, Aita T, Ogaki T and Horie T: Vasodilator effect of urotensin II, one of the most potent vasoconstricting factors, on rat coronary arteries. Eur J Pharmacol 402: R5-R7, 2000.

49. Gendron G, Gobeil F Jr, Belanger S, Gagnon S, Regoli D, D'Orleans-Juste P: Urotensin II-induced hypotensive responses in Wistar-Kyoto (Wky) and spontaneously hypertensive (Shr) rats. Peptides 26: 1468-1474, 2005.

50. Belloni AS, Guidolin D, Ceretta S, Bova S and Nussdorfer GG: Acute effects of endothelins on endogenous adrenomedullin system in the rat heart: immunocytochemical and autoradiographic studies. Int J Mol Med 13: 669-674, 2004.

51. Lopez J and Martinez A: Cell and molecular biology of the multifunctional peptide adrenomedullin. Int Rev Cytol 221: 1-92, 2002.

52. Nagaya N, Mori H, Murakami S, Kangawa K and Kitamura S: Adrenomedullin: angiogenesis and gene therapy. Am J Physiol 288: R1432-R1437, 2005.

53. Nussdorfer GG: Proadrenomedullin-derived peptides in the paracrine control of the hypothalamo-pituitary-adrenal axis. Int Rev Cytol 206: 249-284, 2001.

54. Ziolkowska A, Tortorella C, Nussdorfer GG, Rucinski M, Majchrzak M and Malendowicz LK: Accumulation of steroidogenic acute regulatory protein mRNA, and decrease in the secretory and proliferative acrivity of rat adrenocortical cells in the presence of proteasome inhibitors. Int J Mol Med 17: 865868, 2006.

55. Nussdorfer GG: Cytophysiology of the adrenal cortex. Int Rev Cytol 98: 1-405, 1986.

56. Nussdorfer GG: Paracrine control of adrenal cortical function by medullary chromaffin cells. Pharmacol Rev 48: 495-530, 1996.

57. Delarue C, Contesse V, Lenglet S, Sicard F, Perraudin V, Lefebvre H, Kodjo M, Leboulenger F, Yon L, Gallo-Payet N and Vaudry H: Role of neurotransmitters and neuropeptides in the regulation of the adrenal cortex. Rev Endocr Metab Disorders 2: 253-267, 2001.
58. Naruse M, Obana K, Naruse K, Yamaguchi H, Demura H, Inagami $\mathrm{T}$ and Shizume $\mathrm{K}$ : Atrial natriuretic polypeptide inhibits cortisol secretion as well as aldosterone secretion in vitro from human adrenal tissue. J Clin Endocrinol Metab 64: 10-16, 1987.

59. Hashiguchi T, Higuchi K, Ohashi M, Minamino N, Kangawa K, Matsuo $\mathrm{H}$ and Nawata $\mathrm{H}$ : Porcine brain natriuretic peptide: another modulator of bovine adrenocortical steroidogenesis. FEBS Lett 236: 455-461, 1988.

60. Nawata H, Ohashi M, Haji M, Takayanagi R, Higuchi K, Fujio N, Hashiguchi T, Ogo A, Nakao R, Ohnaka K and Nishi Y: Atrial and brain natriuretic peptide in adrenal steroidogenesis. J Steroid Biochem Mol Biol 40: 367-379, 1991.

61. Ganguly A: Atrial natriuretic peptide-induced inhibition of aldosterone secretion; a quest for mediator(s). Am J Physiol 263: E181-E194, 1992.

62. Mazzocchi G, Malendowicz LK, Andreis PG and Nussdorfer GG: Neurotensin inhibits the stimulatory effect of angiotensin-II and potassium on aldosterone secretion by rat zona glomerulosa cells. Exp Clin Endocrinol 97: 34-38, 1991.

63. Malendowicz LK, Nussdorfer GG, Hinson JP and Vinson GP: Evidence that endogenous neurotensin exerts a tonic inhibitory influence on adrenal zona glomerulosa growth and secretory activity in the rat. Med Sci Res 24: 189-190, 1996.

64. Bornstein SR, Uhlmann K, Haidan A, Ehrhart-Bornstein M and Scherbaum WA: Evidence for a novel peripheral action of leptin as a metabolic signal to the adrenal gland. Leptin inhibits cortisol release directly. Diabetes 46: 1235-1238, 1997.

65. Pralong FP, Roduit R, Waeber G, Castillo E, Mosimann F, Thorens B and Gaillard RC: Leptin inhibits directly glucocorticoid secretion by normal human and rat adrenal gland. Endocrinology 139: 4264-4268, 1998.

66. Glasow A and Bornstein SR: Leptin and the adrenal gland. Eur J Clin Invest 30: 39-45, 2000.

67. Ziolkowska A, Rucinski M, Di Liddo R, Nussdorfer GG and Malendowicz LK: Expression of the beacon gene in endocrine glands of the rat. Peptides 25: 133-137, 2004. 